Journal of Business and Economics Review

Journal homepage: www.gatrenterprise.com/GATRJournals/index.html

J. Bus. Econ. Review 1 (1) 51 - 59 (2016)

\title{
A Study on The Behavioural Aspects of Retail Investors for Investment Decision Making in Telangana State
}

\author{
Jhansi Rani Boda ${ }^{1 *}$, G. Sunitha ${ }^{2}$ and Parag Ray ${ }^{3}$ \\ ${ }^{1}$ Research Scholar, School of Management, National Institute of Technology, Warangal Telangana, India \\ ${ }^{2}$ Assistant Professor, School of Management, National Institute of Technology, Warangal Telangana, India \\ ${ }^{3}$ Student, School of Management, National Institute of Technology, Warangal Telangana, India
}

\begin{abstract}
Objective - Investment is the commitment of funds which have been saved from the current consumption with an expectation of favorable future returns. Investment behavior is concerned with choices made about the purchase of a significant number of securities for an individual or institutional account. Individual investment behavior is relatively a new area of research in behavioral finance. This study aims to identify the various behavioral patterns of retail investors and their investment decision making in the newly formed Telangana state of India.

Methodology/Technique - Data were collected from a sample of 200 retail investors via a structured questionnaire. Factor analysis was then conducted to critically identify the behavioral patterns of the retail investors.

Findings - The findings of this study indicate that the two behavioral factors of Heuristics and Prospect have significant impact on the investment decision making attitudes of the retail investors.

Novelty - As a newly formed state in India, the Telangana state provides potential investment opportunities for retail as well as institutional investors. It is thus, highly imperative to explore how retail investors make investment decisions especially in the newly formed Telangana State in India
\end{abstract}

Type of Paper: Empirical

Keywords: Behavioral Factors; Behavioral Finance; Investment Behavior; Investment Decision Making; Retail Investor. JEL Classification: E22, P25.

\section{Introduction}

Behavioral finance is a field of study that proposes psychology based theories which deviates from logical reasons to explain the irrationality of the investors in investment decision making. Individual investment behavior is greatly influenced by several psychological and emotional biases. These emotional factors such as beliefs, preferences and psychological biases can play a major role in individual investor's investment decision making (Baker \& Riccardi, 2014). The role of the psychological factors in the investment decision-making process has attracted much attention. It was used to explain the association between human emotions with investment decisions (Frank, 1998; Elster, 1998; Hopfenstiz \& Van-Winden, 2008; Loewenstein, 2000). Many

\footnotetext{
${ }^{*}$ Paper Info: Received: September 20, 2016

Accepted: December 21, 2016

* Corresponding author:

E-mail: jhansi@nitw.ac.in

Affiliation: School of Management, National Institute of Technology, India
} 
studies have investigated the investment behavior and decision making styles of retail investors (Odean, 1998; Barber \& Odeon, 2000; Grinblatt \& Keloharju, 2000; Goetzmann \& Kumar, 2008). These studies revealed that most of the time investors over react to market rumors, speculations and economic fluctuations as they were influenced by psychological and emotional biases while making investment related decisions. These psychological and emotional biases caused the investors to deviate from logical and rational thinking. In this regard, it can be deduced that many behavioral biases could influence investors' decision making process (Barberis \& Thaler, 2003).

An individual investor is one who purchases small amounts of securities for his/her own account. Every individual wants his/her savings to be invested in the most secure investment avenue. At the retail level, investors are unique and are highly heterogeneous in nature. Individual investors thus, suffer from several psychological and emotional biases. These biases play an integral role in their decision-making. Bearing that in mind, this study identifies those psychological biases that could influence retail investor's perception of risk and subsequently, their investment decision making. It is observed that investors' level of risk acceptance depends mostly on their personal characteristics and attitudes to risk (Maditinos et al., 2007). To better understand how retail investors in Telangana state make investment decisions, this study takes into consideration some of those influential factors suggested by theories of behavioral finance. In addition to the eight behavioral factors proposed by the Heuristics and Prospect theories, another five factors pertaining to the market situations that exert impact on investment behavior are also added as consideration for this study. They are presented in Table 1 below.

Table 1: Behavioral factors affecting investment decision making

\begin{tabular}{|l|l|}
\hline Group & \multicolumn{1}{|l|}{ Behavioral Variables } \\
\hline Heuristics Theory & - Representativeness \\
& - Overconfidence \\
& - Anchoring \\
& - Availability bias \\
\hline Prospect Theory & - Loss Aversion \\
& - Regret Aversion \\
& - Mental Accounting \\
\hline Herding Effect & - Choice of Stock \\
& - Choice of volume of stock \\
& - Speed of herding \\
& - Other trading actions \\
\hline Market factors & - Price changes \\
& - Market information \\
& - Past trends of stocks \\
& - Fundamentals of underlying stocks \\
& - Oustomers preferences \\
&
\end{tabular}

(Source: Waweru et al., 2008)

\subsection{Statement of the Problem}

In academic terminology, "Investment behavior" is a study of behavioral finance which focuses on the individual's psychological factors that contribute towards effective decision making. Individual investors acquire information from friends, family members, print and electronic media, bankers, brokers and financial advisors for investment decision making (Wang et al., 2006). Moreover, the number of individual investors seems to be increasing rapidly with the latest development in financial systems. With this increase in number 
of investors and the uniqueness of investor's investment decision, there is a need to understand investor's psychology in their decision making. An insight into this may provide explanations to various questions like: "How do investors invest?", "What are the behavioral factors that affect the investment decision making?" This study which focuses on investor's psychology biases can help researchers in identifying the appropriate decision determinants that investors rely on while making investment decisions (Sahi et al., 2013). Identification of factors influencing the retail investor's behavior is important for all the stakeholders of the stock market, as an understanding of what effects investors' behavior and how investors respond to the market movements would affect their future plans and also help their financial advisors to select appropriate asset allocation strategies which can reap maximum returns on investments made.

As a newly formed state in India, the Telangana state provides potential investment opportunities for retail as well as institutional investors. It is thus, highly imperative to explore how retail investors make investment decisions especially in the newly formed Telangana State in India. For the investment companies identifying the most influencing factors on their investors' behavior would affect their future policies and strategies. And also for the government, understanding such factors would affect the required changes in legislation and policies required to maintain investors friendly and efficient investment environment.

\subsection{Research Objectives}

This study aims to

$>$ To identify the most influencing behavioral variables that could affect the investment decisions of individual investors of the Telangana state.

$>$ To confirm whether any psychological biases exist among the retail investors of the Telangana state.

\section{Literature Review}

The first ever account derived from empirical studies noting the behavior of individual investor's appeared in the year 1970. Much of the research then was linked to behavioral finance which focused mainly on the various psychological and emotional biases that were likely to affect investor's behavior and decisions. All such biases include heuristics, anchoring, overconfidence, representative bias, home bias, mental accounting, loss aversion, regret aversion and herding. Research done by Tversky and Kahneman (1974), Daniel et al., (2004), and Barberis et al., (1998) are considered as important theoretical models in identifying the psychological biases that affect investor behavior. In his study, Al-Tamimi (2006) tested 34-items that were categorized by five principal factors namely: self-image/firm-image coincidence, accounting information, neutral information, advocate recommendations, and personal financial needs in the aim to examine its influences on investors' behavior in the UAE financial markets. His study revealed that the most influential individual factors, according to importance as given by investors were "Expected corporate earnings", "Get rich quick", "Stock marketability", "Past performance of the firm's stock", "Government holdings", and "Creation of the organized financial market".

In another study, Bennet et al. (2011) aimed at distinguishing different elements that impacted retail investors' state of mind towards putting resources into value securities exchanges. They conducted an organized survey on 400 retail investors in Tamil Nadu, India. The data were investigated through Factor Analysis. Results indicated that out of the aggregate of 26 factors, only five factors had high impact over retail investors' behavior towards investing in value stocks. Their findings revealed that retail investors in India were giving more emphasis on "Return on equity", "Quality of management", "Return on investment", and "Price to earnings ratio" in making stock selection decisions.

Another study conducted by Joshi et al. (2011) attempted to examine the factors affecting investors' behavior. They found that investors in the city of Ahmedabad and Khambhat (Gujarat) were mostly influenced by factors such as "Financial performance of the company", "Long term performance of the stock", "Sentiment for the stock market", "Expected results of the company (cash dividend, bonus share, buy back of share)", 
"Reputation of firm", "Movement of the stock market", and "Affordability of share price". Their study noted that investors were less influenced by factors such as "Coverage in print media", "Company's ratio analysis", "Corporate social responsibility of the company", and "Traded in multiple stock exchanges".

Merikas et al. (2011) investigated 26 factors which could influence individual investor's behavior in the Greek Stock Exchange by using varimax logarithm of orthogonal rotation of factor analysis. They focused on more than 150 respondents. Results revealed that investors mostly considered factors such as "Expected corporate earnings", "Condition of financial statements", and "Firm status in the industry". The scholar also noted that factors mostly ignored by investors in buying a share include "Political party affiliation', "Statement from politicians and governments", and "Friend and co-worker recommendations".

Nagy and Obenberger (1994) analyzed 34-variables to understand how and to what extent these variables were influencing investors' investment decision. Their findings noted that "Classical wealth-maximization" criteria was significant among respondents while the "Effect of recommendations of brokerage houses", "Individual stock brokers, family members and co-workers" were identified as insignificant.

Shanmugham (2000) also conducted a survey of 201 individual investors to study the information sourced by investors, their perceptions of various investment strategy dimensions and the factors motivating their share investment decisions. It was observed that among the various factors affecting investors' decision making, psychological and sociological factors dominated investors' investment decisions.

Kabra et al., (2010) studied factors, which affect individual investment decisions by using factor analysis. Their study asserted that Indian investors focused initially on 18 variables which were later reduced to 14 variables and finally enumerated into six component factors encompassing Security, Opinion, Awareness, Hedging, Duration and Benefits.

Sashikala and Girish (2015) conducted a study to identify the factors that could influence and affect retail investor's trading behavior in the Indian Equity market. Their results confirmed that factors such as "Broker's advice", "Personal analysis", "Current price of the Equity stock", "Financial analyst's recommendations", "Inclination towards online trading", and "Investor's confidence in advice given by their financial advisor" play a major role in influencing and affecting the trading behavior of the retail investors.

Sultana and Pardhasaradhi (2012) examined the elements that affected Indian equity investor's decision making and behavior. Out of 40 affecting variables, they recognized 10 components which seemed to affect investor's choice. Cronbach's-alpha test was utilized to test the unwavering quality of the 40 variables, which were then classified under fewer than five headings. The factors noted to have affected investors' decision making were "Wealth maximization", "Risk minimization", "Brand perception and social responsibility", "Financial expectation", "Accounting information", "Economic expectations", and "Advocate recommendations".

In their study, Shanmugham and Ramya (2012) applied the theory of reasoned action (TRA) and the theory of planned behavior (TPB) to explain individual investors' behavior. They also attempted to study the influence of social interactions, media and internet on the trading behavior of individual investors. They concluded that social interactions and media have positive relationships with attitude towards trading whereas the factor internet does not seem to influence the respondent attitude towards trading.

\section{Data Collection and Methodology}

As stated earlier, the main objective of this study is to identify the behavioral factors that could influence the investment behavior of retail investors in the Telangana State of India. Adopting the purposive sampling approach, data were collected through a structured questionnaire distributed among 250 sample of these 207 responses were received and only 200 responses were considered suitable for data analysis by using Factor analysis in SPSS 22. The study adopted the 5 Point Likert Scale which is ideal for survey instrument. The target population for the survey included retail investors based in ten districts of Telangana State. The study was conducted during the period of six months i.e. from April 2016 to September 2016. 


\section{Results and Findings}

The Kaiser-Olkin measure of 0.686 suggests a mediocre sampling adequacy. Yet the observation of 0.00 connotes the acceptable Bartlett's Test of Sphericity.

Table 2: KMO and Bartlett's Test

\begin{tabular}{|l|r|r|}
\hline Kaiser- Meyer- Olkin Measure of Sampling Adequacy & & \\
& & \\
\cline { 2 - 3 } & Approx. Chi-Square & 876.683 \\
\hline Bartlett's Test of Sphericity & df & 231 \\
\cline { 2 - 3 } & Sig. & .000 \\
\hline
\end{tabular}

The reliability of the questionnaire was based on Cronbach Alpha with the variable of "Heuristics" being 0.45 , the variable for "Prospect" being 0.41 , and the variable of "Overconfidence" being 0.36 . The Cronbach Alpha shows that these categories for survey instruments are valid and reliable and also suggest that scales used in survey instruments are uni-dimensional. From the test conducted, it was found that the reliability alpha for Herding as factor is 0.47 and for Market is 0.68 . The average individual factor reliability is somewhat around 0.4. In the Principal component analysis, the total variance matrix observed the variables "heuristics1", "heuristics2", "heuristics3", "heuristics4", "prospect1", "prospect2","prospect3", "prospect4", "prospect5", "prospect6", "prospect7". The factor analysis was based component matrix and retaining the value that is greater than 0.4 and it was found that "heuristics1" and "heuristic2" constitute 12 to 15 per cent of variance as is mentioned in Table 3.

Table 3: Total Variance Matrix as SPSS Output

Total Variance Explained

\begin{tabular}{|c|c|c|c|c|c|c|c|c|c|}
\hline \multirow[b]{2}{*}{$\begin{array}{l}\text { Compon } \\
\text { ent }\end{array}$} & \multicolumn{3}{|c|}{ Initial Eigen values } & \multicolumn{3}{|c|}{$\begin{array}{c}\text { Extraction Sums of Squared } \\
\text { Loadings }\end{array}$} & \multicolumn{3}{|c|}{$\begin{array}{c}\text { Rotation Sums of Squared } \\
\text { Loadings }\end{array}$} \\
\hline & $\begin{array}{c}\text { Tota } \\
1\end{array}$ & $\begin{array}{c}\text { \% of } \\
\text { Varianc } \\
\text { e }\end{array}$ & $\begin{array}{l}\text { Cumulat } \\
\text { ive } \%\end{array}$ & $\begin{array}{c}\text { Tota } \\
1\end{array}$ & $\begin{array}{c}\% \text { of } \\
\text { Varianc } \\
\text { e }\end{array}$ & $\begin{array}{l}\text { Cumulati } \\
\text { ve } \%\end{array}$ & $\begin{array}{c}\text { Tota } \\
1\end{array}$ & $\begin{array}{c}\text { \% of } \\
\text { Varianc } \\
\text { e }\end{array}$ & $\begin{array}{c}\text { Cumulativ } \\
\text { e \% }\end{array}$ \\
\hline 1 & 3.43 & 15.618 & 15.918 & 3.43 & 15.618 & 15.618 & 2.54 & 11.555 & 11.555 \\
\hline 2 & 6 & 12.515 & 28.133 & 6 & 12.515 & 28.133 & 2 & 8.651 & 20.206 \\
\hline 3 & 2.75 & 6.900 & 35.033 & 2.75 & 6.900 & 35.033 & 1.90 & 8.021 & 28.228 \\
\hline 4 & 3 & 6.272 & 14.305 & 3 & 6.272 & 41.305 & 3 & 7.890 & 36.118 \\
\hline 5 & 1.51 & 5.842 & 47.147 & 1.51 & 5.842 & 47.147 & 1.76 & 6.794 & 42.911 \\
\hline 6 & 8 & 5.574 & 52.721 & 8 & 5.574 & 52.721 & 5 & 6.741 & 49.653 \\
\hline 7 & 1.38 & 5.014 & 57.736 & 1.38 & 5.014 & 57.736 & 1.73 & 6.558 & 56.211 \\
\hline 8 & 0 & 4.577 & 62.313 & 0 & 4.577 & 62.313 & 6 & 6.102 & 62.313 \\
\hline 9 & 1.28 & 4.367 & 66.680 & 1.28 & & & 1.49 & & \\
\hline 10 & 5 & 4.052 & 70.732 & 5 & & & 5 & & \\
\hline 11 & 1.22 & 3.974 & 74.706 & 1.22 & & & 1.48 & & \\
\hline 12 & 6 & 3.459 & 78.165 & 6 & & & 3 & & \\
\hline 13 & 1.10 & 3.040 & 81.205 & 1.10 & & & 1.44 & & \\
\hline 14 & 3 & 2.894 & 84.100 & 3 & & & 3 & & \\
\hline 15 & 1.00 & 2.501 & 86.601 & 1.00 & & & 1.34 & & \\
\hline 16 & 7 & 2.360 & 88.961 & 7 & & & 3 & & \\
\hline 17 & 0.96 & 2.278 & 91.238 & & & & & & \\
\hline 18 & 1 & 2.041 & 93.280 & & & & & & \\
\hline 19 & 0.89 & 1.980 & 95.259 & & & & & & \\
\hline 20 & 1 & 1.676 & 96.936 & & & & & & \\
\hline 21 & & 1.574 & 98.510 & & & & & & \\
\hline
\end{tabular}




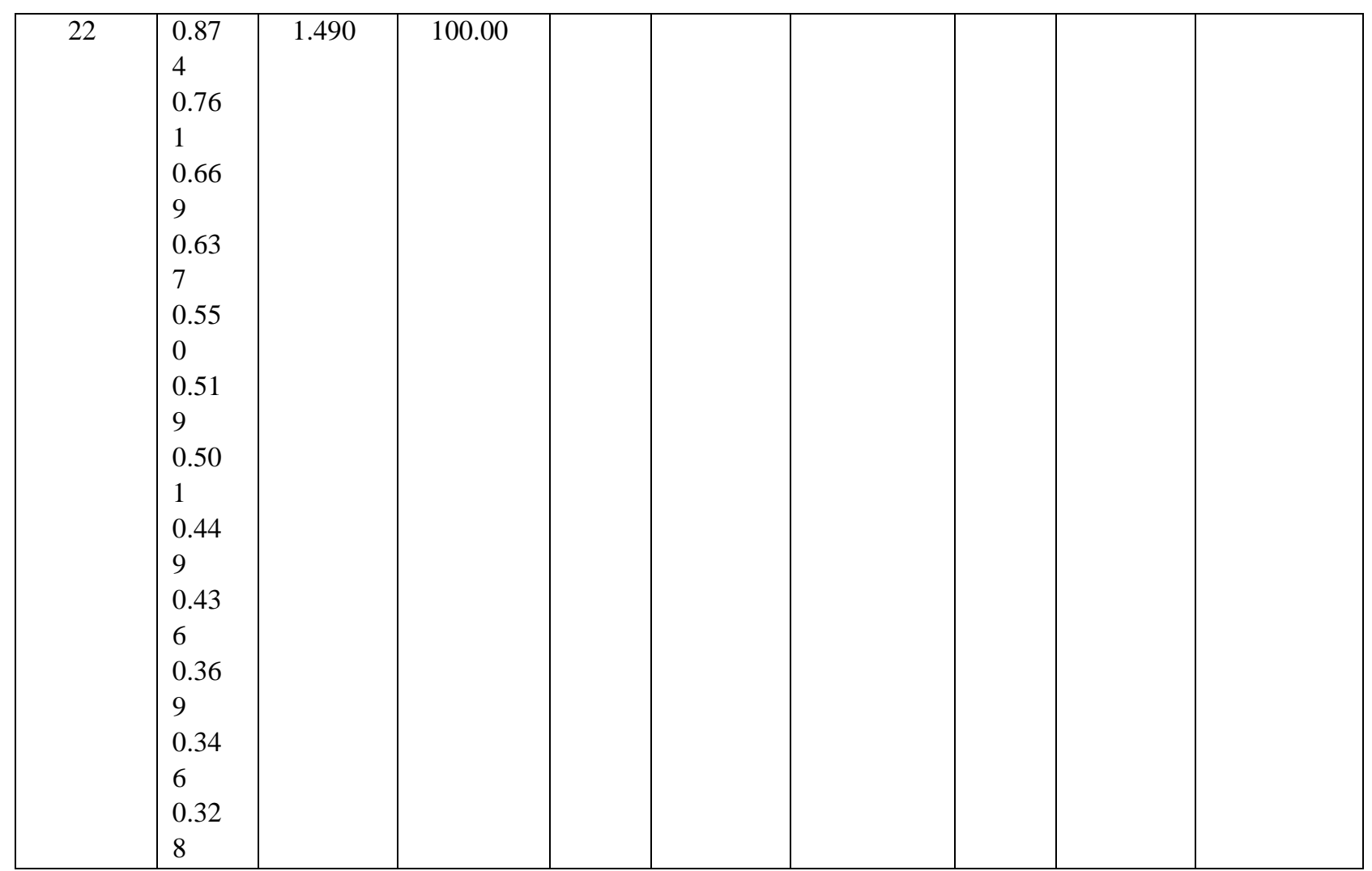

(Extraction Method: Principal Component Analysis)

Amongst the diverse variables noted in Table 3, it appears that "Heuristics" factor emerged as a core variable that could influence the investment behavior of investors across Telangana. Factor one comprised of four variables; three variables (heuristics2, heuristics4, heuristics3) were used to measure the latent variable, heuristics which was loaded into factor one. As per factor extraction, other sub items also loaded well into first factor "heuristics" with an effective factor loading of 0.557 for "market1" and factor loading of 0.552 for "market3". Two items (overconf2 and overconf4) that were used to measure the latent variable of "Overconfidence"; also loaded into factor one and they were regarded as vital by respondents.

The next important variable noted in the study was "Prospect" which comprised of six sub items and only a single item, prospect7, was loaded directly into factor 2 that was used to measure the prospect theory as variable. The third significant variable as per the sample was "Overconfidence". The construct was measured by four sub items (overconf1, overconf2, overconf3, overconf4) yet the sub items (prospect5, prospect1, prospect3) loaded well into the third factor with factor loadings of $0.572,0.570$ and 0.553 respectively.

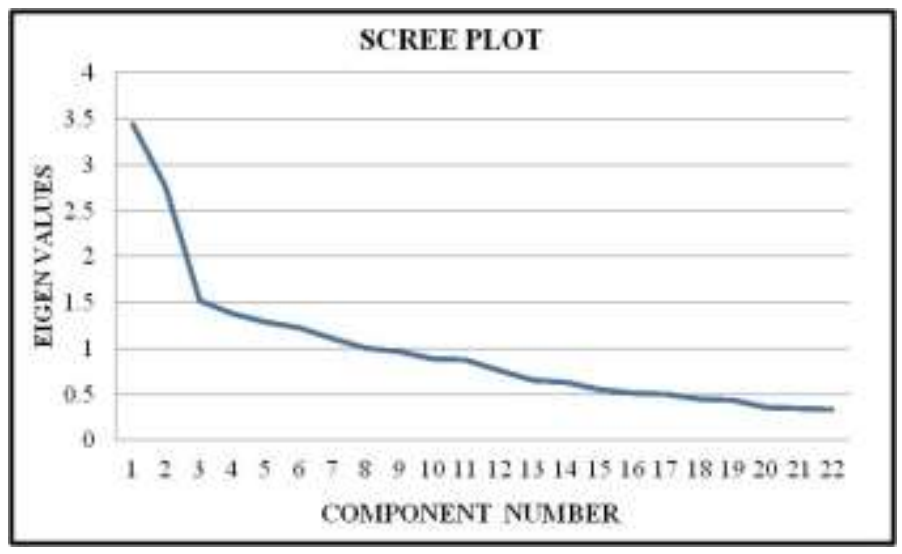

Figure 1: Scree Plot from PCA Output 
The screen plot (Figure 1 above) as churned out from the SPSS output clearly indicates the existence of the impact of the first three components as having maximum possible impact across the sample data. In terms of the impact levels of the behavioral factors influencing the investment decisions of the individual investors of Telangana State, the factor analysis revealed Heuristics as a variable that seems to exert the most potential influence on the psychology of the investors. The next crucial factor is "Prospect". This factor witnessed maximum factor loadings after "Heuristics". The third variable with maximum impact across investors in Telangana is "Overconfidence". As per the factor analysis, "the Heuristics" revealed maximum contribution to overall investor psychology with a maximum variance of 15.618 that is the result shows that the strong evidence for existence of representative bias, over confidence, anchoring and availability bias in decision making criteria. Majority of the surveyed investors considered the recent past performance of any stock at best representing its near future return, hence found it worth investing in stock. The over confidence tendency seems not to be popular among the respondent investors. It was observed that large numbers of surveyed investors were suffering from anchoring bias as they used their purchase price as a reference point for their investment decisions.

Table 4: Component Matrix as SPSS Output Component Matrix ${ }^{\mathrm{a}}$

\begin{tabular}{|c|c|c|c|c|c|c|c|c|}
\hline & \multicolumn{8}{|c|}{ Component } \\
\hline & 1 & 2 & 3 & 4 & 5 & 6 & 7 & 8 \\
\hline Market1 & .557 & -439 & & & & & & \\
\hline Market3 & .552 & -.444 & & & & & & \\
\hline Overconf1 & .506 & & & & & & & \\
\hline Heuristics2 & .488 & & & & & & & \\
\hline Heuristics4 & .473 & & & .415 & & & & \\
\hline Prospect4 & .473 & & & -.410 & & & .421 & \\
\hline Overconf2 & .411 & & & & & & & \\
\hline \multicolumn{9}{|l|}{ Prospect2 } \\
\hline Market2 & .417 & -.588 & & & & & & \\
\hline Overconf4 & .482 & .493 & & & & & & \\
\hline Herding2 & & .486 & & & .486 & & & \\
\hline Overconf3 & & -.436 & & & & & & \\
\hline \multicolumn{9}{|l|}{ Heuristics1 } \\
\hline Prospect5 & & & .572 & .459 & & & .434 & \\
\hline Prospect1 & & & .570 & & & & & \\
\hline Prospect3 & & & .553 & & & & & \\
\hline Market4 & .441 & & & .448 & & & & \\
\hline Herding3 & & & & -.409 & & & & \\
\hline Heuristics3 & .412 & & & & -.473 & & & \\
\hline Prospect7 & & .411 & & & & .477 & & \\
\hline Herding1 & & .471 & & & & & & .503 \\
\hline Prospect6 & & & & & & & & -.486 \\
\hline
\end{tabular}

Extraction Method: Principal Component Analysis

a. 8 components extracted

\section{Conclusion}

From the results noted from this study, it appears that only two variables (Heuristics and Prospect), out of the assumed variables, had exercised a sizeable impact on the individual investor's decision making in Telangana. The factors of "Heuristics" and "Prospect" have been observed to exert a maximum impact on the 
investor's behavioral patterns during the course of this study. The findings thus, support the assumed research objectives as stated in the above section. This study, however, was conducted within the limitations of time, resources and region specificity and sampling techniques. Thus, it is proposed that future studies should include other variables including gender specificity, age group specificity as well as occupation level specificity. The diverse investment options could be explored as part of the research. This study has important applications across behavioral studies with regard to retail investor's decision making contexts and patterns.

\section{References}

Al-Tamimi, H. A. H. (2006). Factors influencing individual investor behavior: an empirical study of the UAE financial markets. The Business Review, 5(2), 225-233.

Baker, H. K. and Riccardi, V. (2014). Investor Behavior- The Psychology of Financial Planning and Investing, Hoboken, NJ: John Wiley \& sons.

Barberis, N., Shleifer, A., \& Vishny, R. (1998). A model of investor sentiment. Journal of financial economics, 49(3), 307-343.

Barberis, N., \& Thaler, R. (2003). A survey of behavioral finance. Handbook of the Economics of Finance, 1, $1053-1128$.

Barber, B. M., Lee, Y. T., Liu, Y. J., \& Odean, T. (2005, January). Who loses from trade? Evidence from Taiwan. In EFA 2005 Moscow Meetings Paper, http://ssrn. com/abstract (Vol. 529062).

Barber, B. \& T. Odeon, (2000). Trading is hazardous to your wealth: the common stock investment performance of individual investors, Journal of Finance, 55, 773-806

Bennet, E., Selvam, D. M., Ebenezer, E., Karpagam, V., \& Vanitha, S. (2011). Investors' attitude on stock selection decision. International Journal of Management \& Business Studies, 1(2), 7-15.

Bennet, E., Selvam, M., Indhumathi, G., Ramkumar, R. R., \& Karpagam, V. (2011). Factors Influencing Retail Investors' Attitude Towards Investing in Equity Stocks: A Study in Tamil Nadu. Journal of Modern Accounting and Auditing, 7(3), 316-321.

Daniel, K. D., Hirshleifer, D., \& Subrahmanyam, A. (2004). A theory of overconfidence, self-attribution, and security market under-and over-reactions (No. 0412006). EconWPA.

Elster, J. (1998). Emotions and economic theory. Journal of economic literature, 36(1), 47-74.

Frank, R. H. Passions within reason. New York: Norton,1988.

Goetzmann, W. N., \& Kumar, A. (2008). Equity portfolio diversification. Review of Finance, 12(3), 433-463.

Grinblatt, M., \& Keloharju, M. (2000). The investment behavior and performance of various investor types: a study of Finland's unique data set. Journal of financial economics, 55(1), 43-67.

Hopfensitz, A., \& Van Winden, F. (2008). Dynamic choice, independence and emotions. Theory and Decision, 64(2-3), 249-300

Joshi, D. J., Khushboo, A., \& Desai, R. (2011). Factors Affecting Equity Investors' Behavior. International Journal of research in Commerce and Management, 2(10), 120-126.

Kahneman, D. and Tversky, A. (1974), Judgement under uncertainity: Heuristics and Biases, Sciences, 185, 1124-1131.

Tversky, A., \& Kahneman, D. (1973). Availability: A heuristic for judging frequency and probability. Cognitive psychology, 5(2), 207-232.

Kabra, G., Mishra, P. K., \& Dash, M. K. (2010). Factors influencing investment decision of generations in India: An econometric study.

Loewenstein, G. (2000). Emotions in economic theory and economic behavior. The American Economic Review, 90(2), 426-432.

Maditinos, D.I., Sevic, Z., and Theriou, N.G. (2007). Investor's behavior in the Athens Stock Exchange (ASE). Studies in Economics and Finance, 24(1), 32-50.

Merikas, A. A., Merikas, A. G., Vozikis, G. S., \& Prasad, D. (2011). Economic factors and individual investor behavior: The case of the Greek stock exchange. Journal of Applied Business Research (JABR), 20(4).

Nagy, R A., \& Obenberger, R.W.. (1994). Factors influencing Investor Behaviour. Financial Analyst Journal, 50(40), 63-68.

Odeon, T., (1998). Are investors reluctant to realise their losses?, Journal of Finance, 53, 1775-98

Sahi, S.K., Arora, A. P., \& Dhameja, N. (2013), An Exploratory Inquiry into the Psychological Biases in Financial Investment Behavior, Journal of Behavioral Finance, 14,94-103. 
Sashikala, P., \& Girish, G. P. (2015). Factors Influencing Retail Investor's Trading Behavior in Indian Equity Market. International Journal of Business and Management, 10(11), 206.

Shanmugham. (2000). Factors Influencing Investment Decisions. In Indian Capital Markets. Tata Mc Graw Hill.

Shanmugham R. and Ramya K. (2012). Impact of Social Factors on Individual Investor's Trading Behavior. Procedia Economics and Finance, (2) 237-246

Sultana, S. T., \& Pardhasaradhi, S. (2012). An empirical analysis of factors influencing Indian individual equity investors' decision making and behavior. European Journal of Business and Management, 4(18), 50-61.

Waweru, N., M., Munyoki, E., and Uliana, E. (2008). The effects of Behavioral factors in investment decision-making: A survey of institutions investors operating at the Nairobi Stock Exchange. International Journal of Business and Emerging Markets, 1(1), 24-41. 